v. 8, n. 4

Vitória-ES, Oct. - Dec. 2011.

p. $01-22$ ISSN 1808-2386 DOI: http://dx.doi.org/10.15728/bbr.2011.8.4.1

\title{
Evaluation of the customer relationship quality and propensity to change mobile telephone operators
}

\author{
Eliane Cristine Francisco Maffezzolli ${ }^{\dagger}$ \\ Pontifícia Universidade Católica do Paraná (PUCPR) \\ Paulo Henrique Muler Prado ${ }^{\Omega}$ \\ Universidade Federal do Paraná (UFPR) \\ Wesley Vieira da Silva ${ }^{¥}$ \\ Pontifícia Universidade Católica do Paraná (PUCPR) \\ Renato Zancan Marchetti ${ }^{\mathfrak{E}}$ \\ Pontifícia Universidade Católica do Paraná (PUCPR)
}

\begin{abstract}
The objective of this article is to shed light on the possible relations between previous events and the customer relationship quality and loyalty and a financial result indicator (lifetime revenue) on the predisposition to change mobile telephone operators. The study was carried out with a non-probabilistic quantitative framework and relied on the hypotheticaldeductive method. The data were obtained from a survey of 493 mobile phone users and were analyzed through a structural equation and logistic regression. The results partially proved the model proposed, because of the particularities of the groups analyzed. We confirmed (directly and indirectly) the premises of a positive and significant effect between Satisfaction, Trust and Commitment and their antecedents. Satisfaction and Loyalty were distinctive elements among the groups with lower propensity to change operators. These results demonstrate some particularities of this market, where consumers perceive supply as being homogeneous, a fact that stimulates the churn rate in Brazil.
\end{abstract}

Key words: Relationship quality; willingness the change operators; logistic regression.

Corresponding authors*:

$\dagger$ Doctorate in business administration from Paraná Federal University (UFPR). Institution: Pontifical Catholic University of Paraná (PUCPR) Address: Rua Imaculada Conceição, 1155, Prado velho, Curitiba-PR - Brazil CEP 80215901.

E-mail: eliane.francisco@pucpr.br Telephone: (41) 32711476

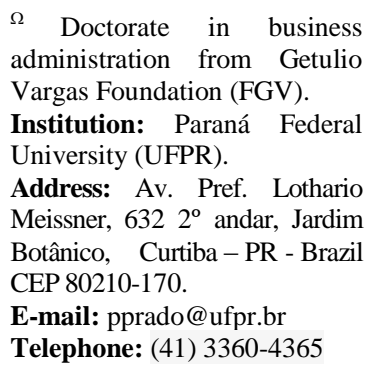

E-mail: pprado@ufpr.br

Telephone: (41) 3360-4365

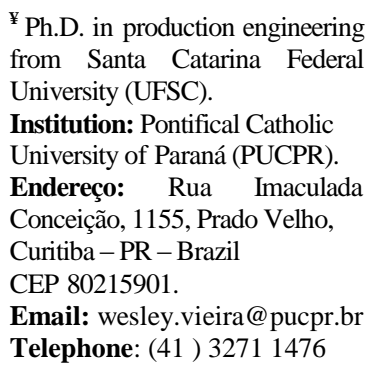

${ }^{£}$ Dr. ès Sciences de Gestion, HECParis.

Institution: Pontifical Catholic University of Paraná (PUCPR). Address: Rua Imaculada Conceição, 1155 , Prado Velho, Curitiba - PR - Brazil CEP 80215901.

E-mail: renato.zancan@pucpr.br Telefone: (41) 32711476

Note from the Editor: This article was accepted by Antonio Lopo Martinez. 


\section{INTRODUCTION}

Concern over the relationship with customers, and consequently the value chain generated by them, is becoming stronger among medium and large companies, according to a survey conducted in Brazil in the first half of 2003 by the Peppers \& Rogers Group Institute. In search of differentiated attitudes and behaviors such as satisfaction and loyalty, with consequent higher revenue, many Brazilian firms have been investing to improve their relationship with customers.

To operationalize a study to illustrate this situation, we decided to investigate, under the prism of relationship marketing, possible relations between perceived quality and perceived value and the relationship quality, and the association of these, as well as loyalty and a financial result indicator in the mobile telephone sector. Besides this, we investigated the predisposition to change operators, through the use of logistic regression.

The literature on customer loyalty and satisfaction starts from the premise that a satisfied customer will make repeated purchases of the same brand, and that this loyalty translates into greater profits (Reichheld \& Sasser, 1990; Fornell, 1992). In the present study we relied on an adaptation of the structural model proposed by Prado (2004) on relationship quality, its antecedents and consequences, adding a financial result variable - lifetime revenue (LTR), and evaluated these constructs and the propensity to change operators expressed by consumers.

We chose the Brazilian mobile telephone sector as the empirical context for two main reasons: (1) this service lends itself well to a relationship study, because customers acquire a line and tend to use it for a medium or long period, and (2) the sector has been growing rapidly (153.7 million lines in the first quarter of 2009) and at the same time is subject to a certain degree of instability among consumers.

According to Teleco, the rate of changing operators, or the churn rate, ranges from $1.9 \%$ to $2.7 \%$ a month. Further according to information disclosed by Teleco, since the monthly average revenue per user (ARPU) among prepaid users (using calling cards) is as low as one-seventh that of postpaid subscribers, companies have begun to put more emphasis on attracting and keeping users with higher consumption, by offering plans with built-in spending controls that are intermediate between prepaid and postpaid calling. In this sense, we examined the propensity to change operators of consumers, in light of the evaluation of the 
relationship quality and its antecedents, as well as the financial result declared by the customers.

\section{LITERATURE REVIEW}

In the literature review we focused on the constructs underpinning the relationship quality along with the antecedents and consequences related to this assessment, and from this formed hypotheses for the model under study.

\subsection{ANTECEDENTS OF RELATIONSHIP QUALITY: PERCEIVED QUALITY AND PERCEIVED VALUE}

Perceived quality depends on consumers' preferences and perceptions (Holbrook \& Corfman, 1985). According to Zeithmal (1988), these perceptions change over time as a result of more information, increased competition and changing expectations. In this respect, the

perceived quality can be defined as the judgment of consumers about the superiority or inferiority of the product or service from the standpoint of attitudes, or the difference between consumers' expectation and perception of the product/service. This expectation, in turn, can be defined as the desired or expected product/service (Zeithmal, Berry \& Parasuraman, 1996).

The term perceived value was used in various forms by Zeithmal (1988) in an exploratory study, leading him to suppose that the assessment of value is personal and idiosyncratic. Among the groups of responses, four stood out: (1) value is low price; (2) value is what I want from a product; (3) value is the quality I get for the price I pay; and (4) value is what I receive for what I give. Therefore, perceived value is the consumer's perception of the cost-benefit relationship obtained from a supplier.

According to the theoretical exposition, there should be a positive relation between perceived quality and value (Eggert \& Ulaga, 2002; Marchetti \& Prado, 2004). In the model proposed, we consider both as being antecedents of satisfaction, but the impact of quality on value, with respect to the cost versus benefit evaluation, is expected, so that:

H1: The higher the perceived quality is, the higher the perceived value will be.

\subsection{RELATIONSHIP QUALITY}

Relationship quality is suggested by Henning-Thurau \& Klee (1997) as being the ability of a relationship to meet the needs of the individual/customer. It integrates the constructs of trust, commitment and quality as mediators of customer satisfaction and retention. Prado (2004), following the antecedent-consequent relation logic between 
satisfaction and perceived quality, proposed an adaptation in the composition of this concept, formed by three variables: satisfaction, trust and commitment. We adopted this second composition in this study.

The concept of satisfaction commonly employed among authors in the area involves subjective comparison (or evaluation) of the expected and received levels of the experience with the good or service (Oliver, 1981; Bergamo \& Giuliani, 2009; Barcelos, Baptista \& Silva, 2010), which is related to the paradigm of disconformity (Oliver, 1981). The role of perceived quality as an antecedent of satisfaction has been recognized in the studies of Fornell et al. (1996), Jonhson et al. (2001), Prado (2004) and Marchetti \& Prado (2004). In this context, we expect that:

H2: The higher the perceived quality is, the higher the customer satisfaction will be.

Bolton (1998), McDougall \& Levesque (2000), Eggert \& Ulaga (2002), Marchetti \& Prado (2004) and Bergamo \& Giuliani, (2009) also have proposed the existence of a positive relation perceived value and satisfaction. Therefore our third hypothesis is:

H3: The higher the perceived value is, the higher the customer satisfaction will be.

Trust is treated with great importance in relationship marketing, since in its essence it implies the notion of confidence and reliability between the partners in a relationship (Garbarino \& Johnson, 1999; Grönroos, 1990; Bergamo \& Giuliani, 2009; Barcelos, Baptista \& Silva, 2010). Complementing this idea, Morgan \& Hunt (1994) argue that this dimension exists in a relationship when one party believes in the integrity and responsibility of the other party to the exchange, and state that the global dynamic of the market brings some premises, such as being an effective competitor requires the company to be a reliable collaborator in the relationship network.

Commitment has been defined as the desire to continue a relationship, and is seen as a good indicator of lasting relationships between the customer and firm (Dwyer, Schurr \& Oh, 1987). This variable is commonly studied in inter-organizational and intra-organizational settings (Mavondo \& Rodrigo, 2001). Morgan \& Hunt (1994) also refer to commitment as a belief that the exchange between partners in a relationship is just as important as guaranteeing the maximum effort to maintain it.

Satisfaction is viewed as one of the elements of the quality of the relationship, and considering the definitions of this quality (satisfaction, trust and commitment), it can be said that these are complementary. As in the empirical model of Prado (2004), we expect a 
positive association between satisfaction on the one hand and trust and commitment on the other, according to hypotheses H4 and H5:

H4: The higher the satisfaction is, the higher the trust will be in the supplier of the service.

H5: The higher the satisfaction is, the higher the commitment will be to the supplier of the service.

The relation between trust and commitment is also indicated as relevant and positive in the studies of Morgan \& Hunt (1994) and Bergamo \& Giuliani, (2009). Complementing this assertion, according to Achrol (1991), trust is the greatest determinant of commitment in a relationship. Since the present study examines a highly competitive context (technological development, rivals with little differentiation in competitiveness, among other aspects), we expect this relation, besides being positive, will be an indication of stronger loyalty to the relationship. Therefore, our sixth hypothesis is:

H6: The higher the trust in the supplier of the service, the greater the commitment to it will be.

\subsection{CONSEQUENCES OF RELATIONSHIP QUALITY: LOYALTY AND FINANCIAL RESULT}

Although this aspect has mainly been analyzed from a more operational perspective, where its concept has been associated with the question of renewed purchasing of a particular product or service (Yi \& Jeon, 2003), Oliver (1999, p. 35) attributes a deeper meaning to the judgment of the consumer regarding the best company: “(...) to become a loyal customer, he must believe that a company or its services continue to offer the best alternative". The author also indicates the prior need for trust and commitment to the relationship.

Another definition and classification of this variable can be found in the study of Dick \& Basu (1994), who discuss the concept of probability of buying from a determined supplier, in a certain quantity and frequency in a given period. The authors also suggest a classification of loyalty into four categories: (1) loyalty; (2) latent loyalty; (3) false loyalty; and (4) no loyalty. Of these, the first is the result of the intention to buy again and the accompanying attitude, defining the "true" state of loyalty.

In relating the influence of satisfaction on loyalty, Oliver (1999) presents six possible relations between these variables, among which we opt in this study for an approximation of the sixth, where initially the individual is satisfied, and by a cumulative positive process can 
reach the stage of true loyalty. Bolton (1998) attributes a positive relation in this respect, tested empirically in the mobile telephone market, on the satisfaction and retention time of this relationship, that is, its loyalty.

Furthermore, McDougall \& Levesque (2000) and Hurley \& Estelami (1998) empirically demonstrated a positive associate between satisfaction, arising from the perception of quality, and future buying intentions, that is, the continuity of the relationship and consequent loyalty of the customer. For these reasons, we expect:

H7: The higher the satisfaction index is, the more loyal customers will be.

After defining loyalty, Oliver (1999) stresses that the best way to reach a state of loyalty is for the customer to believe the company chosen is the best option. Therefore, he considers that besides believing in the company, the consumer must trust the image, information and knowledge, among other factors that enable maintaining the choice over the long term. Also, Grönroos (1997) stresses the importance of the trust and commitment variables in the customer relationship, under the prism of relationship marketing. Based on this, we present hypotheses $\mathrm{H} 8$ and $\mathrm{H} 9$, also in concordance with multiple studies in the area (Prado, 2004; Oliver, 1999; Bergamo \& Giuliani, 2009; Barcelos, Baptista \& Silva, 2010):

H8: The greater the trust in the supplier of services, the stronger the loyalty to this supplier will be.

H9: The greater the commitment to the supplier of services, the stronger the loyalty to this supplier will be.

The financial result can be defined as the financial value of a customer over a determined period of steady buying from the supplier of a product/service. A positive financial result means the customer generates a profit for the company over the time frame for calculation. This concept is connected to the relationship logic, since maintaining a loyal customer base translates into more consistent and higher profits. Yeung \& Ennew (2000) tested the association between loyalty and profitability, where they expected a positive and significant result. This assumption was borne out by the authors by using the American Customer Satisfaction Index (ACSI) with the annual balance sheets of the 200 largest American companies. Johnson et al. (2001) and Guo \& Jiraporn (2005), among others, corroborate this hypothesis. Therefore, our tenth hypothesis is:

H10: The greater the loyalty is, the higher will be the customer's LTR. 
Having presented the hypotheses, we now set out the model proposed, according to Figure 1. The model is an expansion of that developed by Prado (2004), studying relationship quality, aggregating a financial indicator (lifetime revenue - LTR) to the factors relationship quality and loyalty.

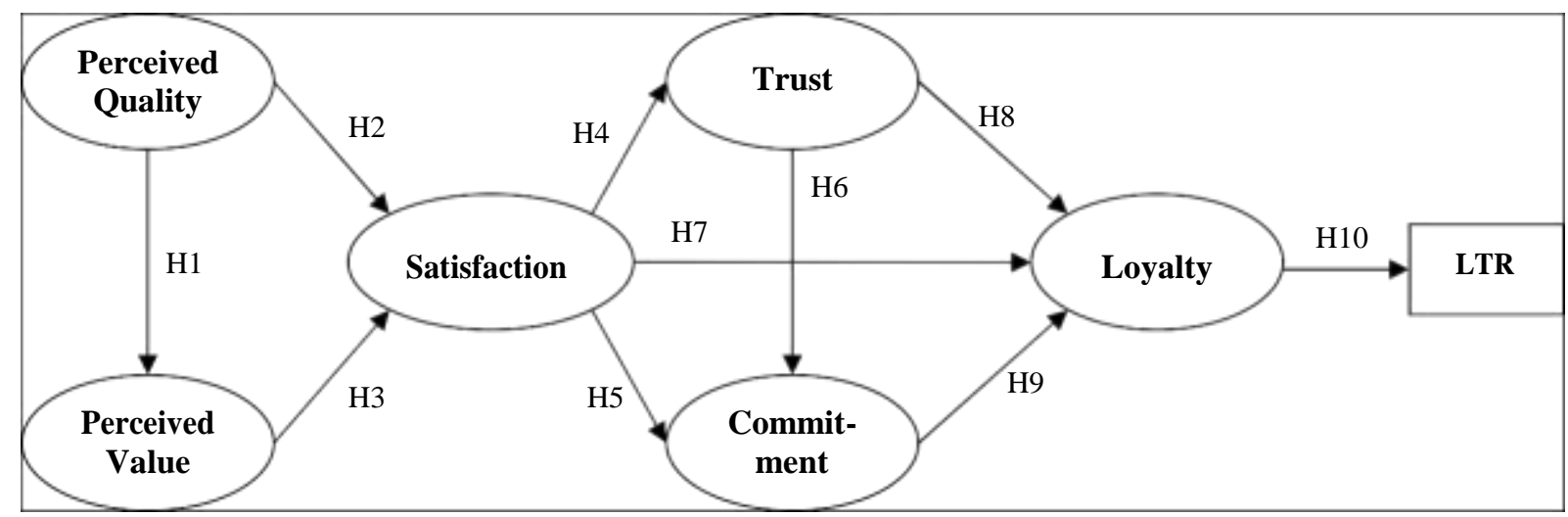

Figure 1 - Proposed model

Source: Prepared by the authors.

\section{METHODOLOGY}

This study reports the results of a cross-sectional survey (Malhotra, 2001). The dimension is quantitative-descriptive and the method applied is hypothetical-deductive (Gill \& Johnson, 1997), based on the theoretical model suggested for testing. To enable the study, the sampling procedure used was non-probabilistic, and also employed the snowball sampling technique, as defined by Malhotra (2001). The number of observations followed the reference of Hair et al. (2005), who suggest 10 observations per item for better fit of the model tested.

All told, we obtained 493 valid responses, 58\% (288) from users of prepaid cell phone plans and $42 \%$ (205) from postpaid subscribers. The gender distribution between the types of mobile phone users was mainly women among prepaid users $(T=48.808, p<0.001)$ and predominantly men among postpaid users $(\mathrm{T}=44.012, \mathrm{p}<0.001)$.

Our data analysis entailed verification of the content validity of the dimensions of the variables proposed in the model and testing the model and study hypotheses between the groups generated from the database. To operationalize the measurement of the variables, we adapted the following scales from the study of Prado (2004): perceived value (4 items), satisfaction (4 items), trust (7 items), commitment (9 items) and loyalty (6 items). The perceived quality scale was adapted from surveys conducted by the National Telecommunications Agency (Anatel) ${ }^{1}$. To measure the financial return (LTR), we used the model of Francisco-Maffezzolli (2007), which in turn is derived from the model proposed by 
Ryals (2005). We used two data sources, first by gathering information directly from customers and second by gathering data on the companies in the database.

The process of analyzing the results involved the following main steps: (1) preparation of the database and verification of the descriptive statistics by univariate and multivariate analysis; (2) verification of the measurement model for the structural analysis proposed with the use of exploratory factorial analysis of the internal consistency of each dimension, defined by Cronbach's Alpha, and confirmatory factorial analysis to establish the convergent and discriminant validity of each construct of the model; (3) calculation of the profitable lifetime, involving definition of parameters to estimate the value of the financial result; (4) generation of the groups for analysis; (5) verification of the proposed structural model by means of structural equations; and (6) use of logistic regression to verify the propensity to change operators.

\section{RESULTS}

The results are presented in the following order: characterization of the sample; a brief description of the data preparation and verification of the model for measurement proposed; generation of the groups; and presentation of the overall results obtained with the model.

\subsection{CHARACTERIZATION OF THE SAMPLE}

Of all the respondents $53 \%$ were women and $47 \%$ were men. The characterization of purchasing power, according to the Brazilian scheme of ranking economic classes (A at the top to $\mathrm{D}$ at the bottom), was $38 \% \mathrm{~B} 2,27 \% \mathrm{~B} 1,26 \% \mathrm{C}, 7 \% \mathrm{~A} 2,1 \% \mathrm{D}$ and $1 \% \mathrm{~A} 1$. The breakdown by operators was $51 \%$ for Tim, $22 \%$ Vivo, $16 \%$ Claro and $11 \%$ Oi (Brasil Telecom). Among the operators, there was a larger concentration of postpaid users of Tim and of prepaid users of Claro. This information is proportional to the presence of each operator in the base.

The average relationship duration for all the operators together was 49.2 months $(\mathrm{SD}=34.944)$, broken down into 41.8 months $(\mathrm{SD}=27,598)$ among prepaid users and 59.6 months $(\mathrm{SD}=41.091)$ for postpaid subscribers. This information was obtained directly from the responses.

Regarding the past pattern of changing operators, 56\% of the 493 respondents had previously used at least one other operator. Therefore, the data were only obtained regarding the relationship with the current operator. The question on the intention to switch revealed that $69 \%$ of the respondents had thought in the past about changing to another operator, and of 
these 308 respondents, 55\% said they might switch in the next six months, while $37 \%$ said they might do so in the next year.

The respondents were asked the amount spent per month in order to obtain an average value to estimate the profitable lifetime. Among prepaid users, the monthly figure was $R \$$ $25.00(\mathrm{SD}=11.150)$, while among postpaid users it was $\mathrm{R} \$ 128.00(\mathrm{SD}=91.348)$. These high standard deviations demonstrate the great heterogeneity of use patterns in the sample studied.

\subsection{PREPARATION OF THE DATA AND VERIFICATION OF THE MODEL}

The result of the factorial analysis confirmed the one-dimensional character of satisfaction (Alpha of 0.912), perceived value (Alpha of 0.887) and loyalty (Alpha of 0.896). This one-dimensional character also was true of trust and commitment, with Alphas of 0.896 and 0.912 . Only the perceived quality supported more than one dimension, these being quality of customer response services (Alpha of 0.894), technical quality (Alpha of 0.876) and payment conditions (Alpha of 0.733 ).

The subsequent factorial analysis to confirm the 47 indicators proposed initially led to keeping 44 of them because of the high model fit. We also employed the compound trust value (CTR), which should be greater than 0.7, and the average variance (AVE), which should be greater than 0.5 (Hair et al., 2005), as indicators of convergent validity. We considered the results obtained to be plausible for the analysis made. We observed the discriminant validity by the pairwise correlation of the variables and by observing the difference between the free and the fixed Chi-square (1). The acceptable values should be lower than 3.5. The results demonstrated there was no overlap of the constructs. The same procedure was used by Moura (2005). The goodness-of-fit indices of the structural model, considering only the latent variables, were acceptable and satisfactory according to the parameters given by Hair et al (2005): $\mathrm{X}^{2}=643.629, \mathrm{GL}=155, \mathrm{p}<0.001, \mathrm{X}^{2} / \mathrm{GL}=4.152$, NFI $=0.925, \mathrm{CFI}=0.942$ and $\mathrm{RMSEA}=0.080$.

\subsection{DETERMINATION OF THE FINANCIAL RESULT INDICATOR}

To determine the financial result indicator (lifetime revenue, or LTR), given the limitations of the field survey (mainly the impossibility of obtaining the usage history of each customer directly from the operator), we used the following calculation structure. First we obtained the gross revenue and EBITDA margin reported by each company. This margin includes the operational contribution of each company. Due to the lack of precise information on the costs per customer of each operator, we used this indicator on each respondent to find 
the individual contribution. In the case of prepaid users who reloaded their credits in an interval shorter or longer than a month, we converted the values to a monthly period.

The principle utilized to determine the value was the sum between the historical value and the future value, considering the financial formulas for future value and present value, respectively. The discount rate was the Selic rate (the benchmark rate in Brazil). The previous time with the operator and projected future retention were obtained from the respondents. To determine the projected continuity time, we treated this element as the expectation of staying with the present operator, according to the following formula:

$$
\begin{gathered}
L T R=H V(\text { historical value })+F V(\text { future value }) \\
H V=M(1+i)^{n} \text {, where: }
\end{gathered}
$$

$M=$ contribution margin (monthly value declared by the respondent $\mathrm{x}$ EBITDA margin of the operator)

$i=$ Selic rate

$n=$ number of months with the operator declared by the respondent.

$$
F V=M(1+i)^{n} \text {, where: }
$$

$M=$ contribution margin (monthly value declared by the respondent x EBITDA margin of the operator)

$i=$ Selic rate

$n=$ intention to stay with the same operator (in months) declared by the respondent.

\subsection{GROUPS FOR ANALYSIS OF THE PROPENSITY TO CHANGE OPERATORS}

Among the 493 respondents, as observed in the categorization of the sample, there was considerable heterogeneity, including gender, age and type of calling plan, among others already discussed in item 4.1. Therefore, we used information declared by the respondents to assign the condition "will change (1)" or "will not change (0)" operator.

Of the respondents, 308 stated they were predisposed to switch, of whom $48 \%$ were women and $52 \%$ men, $57 \%$ used prepaid calling cards and $43 \%$ were postpaid subscribers. Of the consumers with lower propensity to change (185), $61 \%$ were women and $39 \%$ men, while $60 \%$ used prepaid plans and $40 \%$ used postpaid ones. Therefore, there was no significant difference in the composition of the two groups only by the categorical variables gender and type of calling plan.

To further verify the differences between the groups (those who declared they would change- Group 1 or not change - Group 2), we contrasted the weighted average or each latent variable between the groups, as presented in Table 1: 
Table 1: Difference between the Groups

\begin{tabular}{|c|c|c|c|c|c|c|}
\hline Groups** & Variables & $t$-value & Significance & Mean & Standard Deviation & Total Observations \\
\hline & Loyalty* & $\mathrm{T}=11.639$ & $\mathrm{n}<0.001$ & 4.93 & 1.44 & 308 \\
\hline NC & & & & 6.32 & 1.17 & 185 \\
\hline C & Trust* & $\mathrm{T}=10.078$ & $\mathrm{p}<0.001$ & 3.91 & 1.27 & 308 \\
\hline NC & & & & 5.01 & 1.11 & 185 \\
\hline & Commitment* & $\mathrm{T}=11.069$ & $\mathrm{p}<0.001$ & & & \\
\hline$\underset{\mathrm{C}}{\mathrm{NC}}$ & Satisfaction* & $T=10.200$ & $\mathrm{p}<0,001$ & $\begin{array}{l}4.97 \\
4.64\end{array}$ & $\begin{array}{l}1.11 \\
1.34\end{array}$ & $\begin{array}{l}185 \\
308\end{array}$ \\
\hline$\underset{\mathrm{C}}{\mathrm{NC}}$ & Perceived value * & -7 762 & $<0001$ & $\begin{array}{l}5.85 \\
5.30\end{array}$ & $\begin{array}{l}1.15 \\
1.23\end{array}$ & $\begin{array}{l}185 \\
308\end{array}$ \\
\hline$\underset{\mathrm{C}}{\mathrm{NC}}$ & Perceived aur & -8002 & P & $\begin{array}{l}6.17 \\
4.71\end{array}$ & $\begin{array}{l}1.17 \\
0.90\end{array}$ & $\begin{array}{l}185 \\
308\end{array}$ \\
\hline$\underset{\mathrm{C}}{\mathrm{NC}}$ & LTR (lifetime & & & $\begin{array}{c}5.35 \\
6,446.68\end{array}$ & $\begin{array}{c}0.82 \\
12,496.85\end{array}$ & $\begin{array}{l}185 \\
308\end{array}$ \\
\hline YC & rifenue with the & $\mathrm{T}=0.009$ & $\mathrm{P}=0.993$ & $\begin{array}{c}6,458.16 \\
59.79\end{array}$ & $\begin{array}{c}15,514.42 \\
31.94\end{array}$ & $\begin{array}{l}185 \\
308\end{array}$ \\
\hline NC & operator (months) & $1=0.345$ & $P=0.130$ & 58.61 & 39.32 & 185 \\
\hline
\end{tabular}

*The constructs were evaluated by the weighted average

** $\mathrm{C}=$ Change (1) / NC $=$ Not Change (0)

Source: Pepared by the authors

In the differences presented, besides the considerations already made about the indicators leading to the classification of the groups, consideration can also go to the distinction of the general evaluations. In this respect, Group 1 (intention to change operator) showed significantly lower values for the constructs loyalty, trust, commitment, satisfaction, perceived value and perceived quality regarding the respective operator. This assessment appears coherent, since those who declared higher loyalty and relationship quality intended to stay with their existing operator for a longer period.

We should note that the time with the company and revenue contributed to the company did not show significant differences between the two groups. According to the customer relationship literature, more loyal customers should be more profitable and remain with the company longer. However, these premises were not found in our sample. This situation might be the result of the heterogeneity of the sample or a reflection of the dynamic of the mobile telephone market, such as the intensity of competition. Due to the nonprobabilistic nature of the sample, it is not possible to extrapolate these results to other users.

\section{TESTING THE MODEL AND THE HYPOTHESES}

We tested the structural model using six latent variables and one directly observable variable, as already presented. The results of the hypothesis testing are shown in Table 2, with the contrasts between the groups observed: 
Table 2 - Standardized Coefficients (paths) Estimated for the Theoretical Relations Proposed in the Model

\begin{tabular}{|c|c|c|c|c|c|}
\hline Structural Relation & Groups & $\begin{array}{c}\text { Standardized } \\
\text { Coefficient }\end{array}$ & $\begin{array}{c}t- \\
\text { value* }\end{array}$ & $\begin{array}{l}\text { Hypothe } \\
\text { sis }\end{array}$ & $\begin{array}{c}\text { Hypothesis } \\
\text { Verification Status }\end{array}$ \\
\hline $\begin{array}{c}\text { Perceived Quality } \rightarrow \text { Perceived } \\
\text { Value }\end{array}$ & $\begin{array}{c}\mathrm{C} \\
\mathrm{NC}\end{array}$ & $\begin{array}{l}0.751 \\
0.690\end{array}$ & $\begin{array}{l}8.861 * \\
7.664 *\end{array}$ & H1 & Confirmed \\
\hline \multirow{2}{*}{ Perceived Quality $\rightarrow$ Satisfaction } & & 0.505 & $5.179^{*}$ & H2 & Confirmed \\
\hline & $\underset{\mathrm{CC}}{\mathrm{NC}}$ & $\begin{array}{l}0.182 \\
0.390\end{array}$ & $\begin{array}{l}2.385 * \\
4.658^{*}\end{array}$ & \multirow{2}{*}{$\mathbf{H 3}$} & $\begin{array}{l}\text { Confirmed } \\
\text { Confirmed }\end{array}$ \\
\hline Perceived Value $\rightarrow$ Satisfaction & NC & 0.766 & $9.286^{*}$ & & Confirmed \\
\hline \multirow{3}{*}{$\begin{array}{c}\text { Satisfaction } \rightarrow \text { Trust } \\
\text { Satisfaction } \rightarrow \text { Commitment }\end{array}$} & $\begin{array}{c}\mathrm{C} \\
\mathrm{NC}\end{array}$ & $\begin{array}{l}0.634 \\
0.669\end{array}$ & $\begin{array}{l}9.621 * \\
8.239 *\end{array}$ & \multirow{3}{*}{$\begin{array}{l}\text { H4 } \\
\text { H5 }\end{array}$} & $\begin{array}{l}\text { Confirmed } \\
\text { Confirmed }\end{array}$ \\
\hline & & 0.354 & $5.569 *$ & & Confirmed \\
\hline & NC & 0.354 & $4.648 *$ & & Confirmed \\
\hline Trust $\rightarrow$ Commitment & $\begin{array}{c}\mathrm{C} \\
\mathrm{NC}\end{array}$ & $\begin{array}{l}0.629 \\
0.685\end{array}$ & $\begin{array}{l}8.063^{*} \\
7.122^{*}\end{array}$ & H6 & $\begin{array}{l}\text { Confirmed } \\
\text { Confirmed }\end{array}$ \\
\hline Satisfaction $\rightarrow$ Loyalty & $\begin{array}{c}\mathrm{C} \\
\mathrm{NC}\end{array}$ & $\begin{array}{l}-0.033 \\
-0.285\end{array}$ & $\begin{array}{l}-0.389 \\
-0.915\end{array}$ & $\mathbf{H 7}$ & $\begin{array}{l}\text { Not Confirmed } \\
\text { Not Confirmed }\end{array}$ \\
\hline Trust $\rightarrow$ Loyalty & $\begin{array}{c}\mathrm{C} \\
\mathrm{NC}\end{array}$ & $\begin{array}{c}0.111 \\
-0.581\end{array}$ & $\begin{array}{r}0.865 \\
-0.961\end{array}$ & H8 & $\begin{array}{l}\text { Not Confirmed } \\
\text { Not Confirmed }\end{array}$ \\
\hline Commitment $\rightarrow$ Loyalty & $\begin{array}{c}\mathrm{C} \\
\mathrm{NC}\end{array}$ & $\begin{array}{l}0.792 \\
0.680\end{array}$ & $\begin{array}{l}4.411^{*} \\
1.974^{*}\end{array}$ & H9 & $\begin{array}{c}\text { Confirmed } \\
\text { Not Confirmed }\end{array}$ \\
\hline Loyalty $\rightarrow$ LTR & $\begin{array}{c}\mathrm{C} \\
\mathrm{NC}\end{array}$ & $\begin{array}{c}-0.035 \\
0.031 \\
\end{array}$ & $\begin{array}{c}-0.588 \\
0.411\end{array}$ & H10 & $\begin{array}{l}\text { Not Confirmed } \\
\text { Not Confirmed }\end{array}$ \\
\hline
\end{tabular}

* Results significant at 0.001

Group C (change): $\mathrm{X}^{2}=604.257 \mathrm{GL}=180 . \mathrm{p}<0.001, \mathrm{X}^{2} / \mathrm{GL}=3.357, \mathrm{NFI}=0.870 . \mathrm{CFI}=0.904$ and $\mathrm{RMSEA}=$ 0.088

Group NC (not change): $\mathrm{X}^{2}=446.085 \mathrm{GL}=180 . \mathrm{p}<0.001, \mathrm{X}^{2} / \mathrm{GL}=2.478, \mathrm{NFI}=0.857, \mathrm{CFI}=0.908$ and RMSEA $=0.090$

Source: Prepared by the authors

The fit indices of both models can be considered plausible according to confirmatory factor analysis (CFA). However, we believe a base with more observations for each group could offer better fit. The result of the overall model was based on 493 observations, 185 in Group NC (not willing to change) and 308 in Group C (willing to change), as already presented.

Hypothesis 1, supported by the findings of Eggert \& Ulaga (2002) and Marchetti \& Prado (2004), showed a positive and significant relationship. The interpretation of this relationship indicates a situation where the higher the perceived quality is (defined by technical quality, excellence of customer response and payment conditions), the greater will be the impact on the perceived value (defined by effort, time and cost of the relationship). Both groups proved this situation $(\beta=0.751, p<0.001$ for Group $C$ and $\beta=0.690, p<0.001$ for Group NC). This situation indicates that regardless of the customer profile in terms of propensity to switch brands (particularly in the context of mobile phone operators), the assessments of quality and value are important. The association between perceived quality and satisfaction (H2), with this order of antecedent and consequence, has been recognized in 
the studies of Fornell et al. (1996), Jonhson et al. (2001) and Marchetti \& Prado (2004), among others.

Perceived value is also considered to be an antecedent of satisfaction and constitutes the economic dimension (cost versus benefit) of the proposed model. This relation, already noted by Bolton (1998), McDougall \& Levesque (2000), Eggert \& Ulaga (2002) and Marchetti \& Prado (2004), is positive and relevant, as observed in Group C. However, perceived quality is not the only antecedent of satisfaction according to the literature. Therefore, it might be that other elements, such as trust and commitment, are relevant for people to tend to stick with brands.

Hypotheses 4, 5 and 6, which replicate the proposal of Prado (2004) about the quality of the relationship, were borne out by both groups (C and NC). Garbarino \& Johnson (1999) also found evidence of a complementary association between these variables, making the positive and significant relation between satisfaction, trust and commitment plausible.

Although studies such as those by McDougall \& Levesque (2000), Hurley \& Estelami (1998), Bergamo \& Giuliani (2009) and Barcelos, Baptista \& Silva (2010) empirically demonstrate the positive and significant relation of satisfaction with the intention to purchase and continue the relationship (these being loyalty indicators), it should be mentioned that there is a good deal of controversy in the literature about this relation. Some authors, such as Jones \& Sasser (1995), have mentioned an association that is not necessarily linear in this relationship (satisfaction - loyalty). Those authors also comment that environmental characteristics, such as high cost of switching, promotional advantages and governmental regulations, are among factors that stimulate false loyalty and a 'weak' relation with satisfaction, since in this context the relationship time is not solely defined by the user's choice, but also by other variables that offer convenience or impose constraints. In the present study, both groups did not prove this association, as the result of hypothesis 7 demonstrates.

Hypothesis 8, which posits a significant association between trust and loyalty, was not confirmed in either of the two groups. According to Oliver (1999), the continuity of the relationship between a company and consumer occurs partly by the latter's belief that the choice is best. At this moment, the trust in the brand, the company or its image (for example) is a strong indicator of loyalty to it. This relation, however, rejected in the setting of mobile phone service, can be understood by the Brazilian context itself, by considering some elements, such as the complaint rates among all operators in the country, according to the 
records of Procon (the consumer compliant office), and perhaps the characteristics of the market structure (oligopoly).

The association of commitment with loyalty, present in H9, was confirmed only for group C. This result agrees the those of Gröonros (1997) and Bergamo \& Giuliani (2009), in affirming the importance of this construct on the continuity of a relationship, and also with Oliver (1999) regarding the comprehension of loyalty by phases, where the higher the commitment is, the greater will be the probability of turning a situation of affective or conative loyalty into loyalty of action.

With respect to hypothesis 10 , where we expected a positive association between loyalty and the financial index (LTR), although the literature generally indicates this positive association exists (Yeung \& Ennew, 2000; Johnson et al., 2001; Guo \& Jiraporn, 2005), some authors question the linearity and significance of the affinity of the constructs. Gurau \& Ranchhod (2002) comment on the difficulty of obtaining a positive relation, considering the subjectivity of measuring the latent variables or the bias that cross-referencing the data can have due to some other factor. These limitations raised by the authors include the type of data collection (cross sectional). It is possible that longitudinal monitoring might offer more concrete information. Therefore, we consider that this hypothesis was not borne out in either group.

In complementary form to the study objectives, we also observed the indirect effects in the structural model. The values in Table 3 show the results obtained:

Table 3 - Indirect Effects between the Latent Constructs of the Structural Model

\begin{tabular}{lcc}
\hline $\begin{array}{c}\text { Indirect effects between the constructs } \\
\text { of the model }\end{array}$ & $\begin{array}{c}\text { Standardized coefficients } \\
\text { (Group C) }\end{array}$ & $\begin{array}{c}\text { Standardized coefficients } \\
* \\
\text { (Gropu NC) }\end{array}$ \\
\hline Perceived Quality $\rightarrow$ Satisfaction & $0.293^{*}$ & $0.529^{*}$ \\
Perceived Quality $\rightarrow$ Trust & $0.506^{*}$ & $0.476^{*}$ \\
Perceived Value $\rightarrow$ Trust & $0.247^{*}$ & $0.513^{*}$ \\
Perceived Quality $\rightarrow$ Commitment & $0.601^{*}$ & $0.577^{*}$ \\
Perceived Value $\rightarrow$ Commitment & $0.294^{*}$ & $0.622^{*}$ \\
Satisfaction $\rightarrow$ Commitment & $0.399^{*}$ & $0.458^{*}$ \\
Perceived Quality $\rightarrow$ Loyalty & $0.506^{*}$ & $0.492^{*}$ \\
Perceived Value $\rightarrow$ Loyalty & $0.247^{*}$ & $0.530^{*}$ \\
Satisfaction $\rightarrow$ Loyalty & $0.666^{* *}$ & $0.976^{*}$ \\
Trust $\rightarrow$ Loyalty & $0.498^{*}$ & $0.900^{*}$ \\
\hline *
\end{tabular}

* values significant at 0.001

Source: Analysis of the data from the project

The indirect effects demonstrate that in general ( 7 of the 10 indirect relations) the constructs for evaluating the relationship, particularly those that explain satisfaction and loyalty, can be observed with greater weight among the evaluations of the group that would 
not change operators. The investigation of these effects is relevant since the next step of the study was to verify the predisposition to change operators, considering the possible explanatory power of these constructs. Therefore, direct and indirect effects can help the comprehension of the behavior of these variables, since the linearity of some relations, such as between satisfaction and loyalty, may not be sufficient to understand the results obtained.

\section{EVALUATION OF THE PROPENSITY TO CHANGE MOBILE TELEPHONE OPERATORS}

Besides the structural assessment carried out, which demonstrates the predominance of linear relations between the constructs analyzed, to assess the respondents' propensity to change operators we used a logistic regression model in complementary form to try to map the willingness to change. This analytic model follows the principles of multiple regression, with the condition that the dependent variable must be categorical, according to the following formula:

$$
\begin{aligned}
& Y_{i}=\beta_{0}+\beta_{1} X_{i}+\varepsilon_{i} \\
& Y_{i}=\left\{\begin{array}{l}
1=\text { "Troca" } \\
0=\text { "Não Troca" }
\end{array}\right.
\end{aligned}
$$

So that:

$$
\begin{aligned}
& Y_{i}=1 \rightarrow P\left(Y_{i}=1\right)=\pi_{i} \\
& Y_{i}=0 \rightarrow P\left(Y_{i}=0\right)=1-\pi_{i}
\end{aligned}
$$

In this case, the independent variables can be categorical or continuous. The origin equation explains the probability that $\mathrm{Y}$ will occur when $\mathrm{X} i$ occurs (Field, 2005). Therefore, to evaluate which elements can affect the consumers" condition of "will change" or "will not change" mobile phone operators, we tested (in continuous variable character) the constructs for evaluating the relationship with the respective weighted means. We also tested categorical variables such as gender, type of calling plan (prepaid or postpaid), and continuous ones such as time of relationship with the operator (in months) and the declared value of the investment in the services, indicated in this study as the LTR.

This analysis entailed two steps. In the first, we selected cases randomly, according to the random transformation of the numbers by SPSS. For this purpose we selected $70 \%$ of the sample, or 348 cases. The results from this initial portion of respondents indicated acceptable fit indices for the situation analyzed. Therefore, we considered step 2 (according to the 
forward LD model) as being the most adequate (Chi-square=86.858; $\mathrm{SD}=2 ; \mathrm{p}<001)$. The Hosmer \& Lemeshow value was also adequate (Chi-square=3.009; $\mathrm{SD}=8 ; \mathrm{p}=0.934$ ). The predictive capacity was $73 \%$. The most relevant variables were satisfaction and loyalty, respectively, with $\exp (\mathrm{B})$ values of 0.593 for loyalty and 0.616 for satisfaction.

Subsequently we performed logistic regression on the entire database, with the forward LR method. This method automatically calculates various models until attaining the best fit. In particular, in this study this led to the choice of model 2 (step 2), with Chi-square = 131.616, $\mathrm{SD}=1, \mathrm{p}<0.001$. According to the Hosmer \& Lemeshow fit index (Chi-square $=$ $3.519, \mathrm{SD}=8, \mathrm{p}=0.898$ ), the values are plausible (other fit indices: $-2 \log$ likelihood $=520.813$ / Cox \& Snell=0.234 / Nagelkerke R square=0.319). The predictive power of the model is $73.4 \%$. The values confirmed the results found in the test conducted with part of the sample, which was chosen randomly.

Of the variables tested, only loyalty and satisfaction were relevant to identify factors that can affect the propensity to change operators, as shown in Table 4.

Table 4: Significant Variables in the Logistic Regression

\begin{tabular}{lccc}
\hline Variable & B & Wald & $\operatorname{Exp}(\mathrm{B})$ \\
\hline Loyalty & -0.569 & 29.141 & 0.569 \\
Satisfaction & -0.449 & 16.530 & 0.638 \\
Constant & 6.101 & 97.865 & 446.114 \\
\hline
\end{tabular}

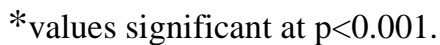

Source: Prepared by the authors

With respect to this result, we highlight that the other constructs (quality, trust, commitment and perceived value), although also indicated in the literature as variables that can affect consumers' propensity to change suppliers, were not distinctive for this propensity in the present study. This suggests a reflection on the results of the structural model. Despite the direct and positive relations between the constructs, as presented in Table 2, the number of factors that might have been very important in determining the propensity to switch is reduced (here we suggest the role of satisfaction and loyalty), as well as being nonlinear. Therefore, we believe the use of complementary analytical models is helpful, since what is sought is to explain, from different perspectives, the effect of the consumer's evaluation of the variables studied.

According to the values presented in Table 1, the constructs loyalty and satisfaction were more important, which can already indicate greater relative importance of these items in the explanation of this model, besides corroborating the results of the logistic regression. 
It is also important to note that according to the relationship literature, the value of the financial result and time of the relationship with the operator should be higher and significant for the NC group. However, we did not obtain this result. This situation might be due to the sample's profile (non-probabilistic and highly heterogeneous), or the profile of the sector itself, in which frequent special promotions and offers to consumers lead to a particular and hard-to-predict behavioral pattern.

Therefore, it can be said that the more unsatisfied the consumer is, the greater will be the tendency to switch. Utilizing the value of $\operatorname{Exp}(B)$ as a reference, we calculated the probability of changing according to the elements evaluated. With respect to loyalty, the probability of changing went down to $0.362((0.569) / 1+0.569)$, while for satisfaction this decline was to $0.389((0.638) / 1+0.638)$. This situation demonstrates the importance of these elements in the evaluation of the consumer in relation to the respective purchasing behavior.

\section{DISCUSSION OF THE RESULTS}

The context of mobile telephone service demonstrated, according to the structural analysis, that satisfaction is not a determining factor (at least among the consumers analyzed) of loyalty. Satisfaction alone did not show a direct and linear positive association on the continuity of the relationship. An opposite situation was observed by Moura (2005), who found a positive and relevant relation between these variables, also in the mobile telephone sector. This situation demonstrates that further studies of this question are necessary. The averages obtained to measure satisfaction were higher in that study than in the present one. Besides the specificity of the state, other differences, such as the use of a 5-point Likert scale by Moura, might explain the contrasting results obtained.

On the other hand, these two variables demonstrate higher influence on the comprehension of the intention to change operators among the consumers studied. Therefore, it is possible to suggest that although we did not observe a direct and linear relation between satisfaction and loyalty, the assessment of these two elements is relevant to the propensity to change. According to the values indicated in Table 3, this relation is relevant, and according to the results of the logistic regression, individuals who are less satisfied tend to be lees loyal, and thus more likely to switch operators (at least in the short term, as declared by the respondents).

In contrast, trust, considered to be a fundamental ingredient for a satisfactory customer relationship (Garbarino \& Johnson, 1999; Dwyer, Schurr \& Oh, 1987; Morgan \& Hunt, 
1994), was shown to be a preceding construct of loyalty by Prado (2004) and Sidersmukh, Singh \& Sabol (2002). Although a direct association was rejected here, the impact of trust on commitment was relevant, making it possible to consider that trust exercises a certain influence on loyalty through the user's commitment. In the real setting, it is plausible to imagine that the user receives certain stimuli to trust the operator (such as image, response to customer complaints and queries and quality of the services, among others). Development of a feeling of trust by the company tends to trigger the desire to continue the relationship by the customer and the belief that the company is the best option to resolve the customer's problems and needs. This fact, if confirmed, tends to keep the customer loyal to the company. However, this variable appears not to have a direct effect on the propensity to change operators, according to the result of the logistic regression.

Added to this context is the positive influence of satisfaction on commitment, as proposed by Prado (2004) and Bergamo \& Giuliani (2009), based on the premise that the consumer's commitment leads to a lasting relationship with the company. Therefore, satisfaction is taken as one of the vectors that cause that commitment. Besides this, there is the positive and significant effect of perceived value on satisfaction, which allows inferring the valorization of the economic perspective proposed by Zeithmal (1988) and corroborated by Marchetti \& Prado (2004), in the evaluation of customer satisfaction. We observed these findings only in the structural analysis, so despite the positive and significant impact of this association, we suggest that future studies should investigate, from other perspectives, the influence and explanatory power of these constructs on the propensity to change.

Finally, from the standpoint of relationship marketing, the lack of statistically significant confirmation of the relations proposed in hypotheses 7, 8 and 10, and partially in 2 and 9, might have been due to the particular nature of the sector, or the heterogeneous profile of the sample, facts that again urge future investigations specifically according to user profile.

\section{FINAL CONSIDERATIONS}

Although we recognize it is not possible to generalize the empirical findings reported here, we can highlight as the main contribution of this study the use of logistic regression to understand (and try to predict) consumer behavior, as well as the effort to establish the complementarity of the results, obtained by testing the structural model.

The relation between satisfaction, loyalty and the financial result index were not confirmed in direct and linear form (results obtained by using structural equations), especially 
the association between satisfaction and loyalty on the one hand and the financial result on the other. This situation suggests a certain restiveness, since the theoretical premises imply a positive relation of these two pairs of constructs.

The logistic regression showed that customer satisfaction and loyalty are essential elements to determine the propensity to change operators. In other words, the evaluation of these variables is relevant, but not linear, as demonstrated by the results of the structural model. These results corroborate the premises found in the customer relationship literature.

Therefore, we suggest that the use of logistic regression, as a way to understand the propensity of customers to change suppliers, can help better understand the results obtained. The SEM basically demonstrated linear relations between the variables. In contrast, the logistic regression permitted recognition of the independent variables that best explain the behavior. Therefore, the complementary use of these statistical tools allowed a better understanding of the propensity of mobile phone users to change operators.

In closing, this study reflects the richness of the information on the interactions between the behavioral aspects and financial result in evaluation of the customer relationship by companies and suggests that the systematized control of this information can support the marketing strategies of mobile telephone operators.

\section{REFERENCES}

ACHROL, R. Evolution of Marketing Organization: New Forms for Turbulent Environments. Journal of Marketing. n. 55, 1991

ANDERSON, E. Customer Satisfaction and Price Tolerance. Marketing Letters, July 1996. BARCELOS, E.M.B; BAPTISTA, P.P; SILVA, W.V; Relações Existentes entre a Avaliação de que uma Organização é Socialmente Responsável e a Satisfação, a Confiança e a Lealdade de seus Clientes. Anais do EMA, p. 52, 2010.

BERGAMO, F.V.M; GIULIANI, A.C. A Lealdade do Estudante baseada na Qualidade do Relacionamento: Uma análise em Instituições de Ensino Superior. Anais do Enanpad 2009.

BERGER, P. D. NASR, N.I. Customer Lifetime Value: Marketing Models and Applications. Journal of Interactive Marketing. v12, p. 17-30. 1998.

BOLTON, R.N. A Dynamic Model of the Duration of the Customer's Relationship with a Continous Service Provider: The Role of Satisfaction. Marketing Science. v 17, n.1, 1998. 
DICK, A. S; BASU, K. Customer Loyalty: Toward an Integrated Conceptual Framework. Journal of Academic Marketing Science. Spring, v.22, 1994.

DWYER, F.R; SCHURR, P.H; OH, S. Developing Buyer-Seller Relationships. Journal of Marketing. v.61, n.2, April 1987.

EGGERT, A; ULAGA, W. Customer perceived value: a substitute for satisfaction in business markets? The journal of Business \& Industrial Marketing. v.17, 2002

FIELD, A. Discovering Statistics Using SPSS. Sage, London: 2005.

FORNELL, C. A National Customer Satisfaction barometer: The Swedish experience. Journal of Marketing, n.56, 1992

; JOHNSON, M.D; ANDERSON, E.W; CHA, J; BRYANT, B.E. The American Customer Satisfaction Index: Nature, purpose and findings. Journal of Marketing, v. 60. 7$18,1996$.

GARBARINO, E; JOHNSON, M.S. The Different Roles of Satisfaction, Trust, and Commitment in Customer Relationships. Journal of Marketing. v.63, April 1999.

GILL, J.; JOHNSON, P. Research Methods for Managers. 2nd ed. London: Sage, 1997. GUO, C.; JIRAPORN, P. Customer satisfaction, net income and total assets: An exploratory study. Journal of Targeting, Measurement and Analysis for Marketing. v.13, 2005. GURAU, C; RANCHHOD, A. How to calculate the value of a Customer. Measuring customer satisfaction: A platform for calculating, predicting and increasing customer profitability. Journal of Targeting, Measurement and Analysis for Marketing, March 2002.

GRÖNROOS, C. Relationship approach to the marketing function in service contexts: the marketing and organizational behavior interface. Journal of Business Research, v.20. n.1, 1990.

; Keynote paper: From Marketing mix to Relationship Marketing- towards a paradigm shift in marketing. Management Decision, 1997.

HAIR JUNIOR, J.F. Análise Multivariada de dados. 5 ed. Porto Alegre: Bookman, 2005. HENNING-THURAU, T; KLEE, A. The Impact of Customer Satisfaction and Relationship Quality on Customer Retention: A Critical Reassessment and Model Development. Psychology \& Marketing, 1997. 
HOLBROOK, M; CORFAMN, K. Quality and Value in the consumption experience: Phaedrus rides again. in Perceived Quality, J. Jacoby and J.Olson, eds. Lexington, MA: Lexingthon Books, 1985

HURLEY, R.H; ESTELAMI, H. Alternative indices for monitoring customer perceptions of service quality: A comparative evaluation in a retail context. Journal of the Academy of Marketing Science,v.26, 1998.

JOHNSON, M. D; GUSTAFSSON, A; ANDREASSEN, T. W; LERVIK, L; CHA, J. The Evolution and Future of National Customer Satisfaction Index Models. Journal of Economic Psychology, v.22, 217-245, January 2001.

JONES, O.T; SASSER, W.E. Why Satisfied Customers Defect. Harvard Business Review. n.73, 1995.

MALHOTRA, N. K. Pesquisa de Marketing: Uma Orientação Aplicada. 3rd ed. Porto Alegre: Bookman, 2001.

MARCHETTI, R.; PRADO, P. H. M. Avaliação da Satisfação do Consumidor Utilizando o Método de Equações Estruturais: Um modelo Aplicado ao setor elétrico brasileiro. RAC. v.8, n.4, October-December 2004.

MAVONDO, F.T; RODRIGO, E.M. The effect of relationship dimensions on interpersonal and interorganizational commitment in organizations conducting business between Australia and China. Journal of Business Research. n.52, 2001.

MCDOUGALL, G.H.G; LEVESQUE, T. Customer satisfaction with services: Putting perceived value into the equation. The Journal of Services Marketing. Santa Barbara, 5th ed, v.14, 2000.

MORGAN, R., HUNT, S. The Commitment - Trust Theory of Relationship Marketing. Journal of Marketing, v.58, n.3, July 1994.

MOURA, A. C. Validação do Modelo de Satisfação ACSI Modificado no Setor de Telefonia Móvel. XXIX Enanpad, 2005.

OLIVER, R. L. Measurement and Evaluation of Satisfaction Processes in Retail Settings. Journal of Retailing. v 57, n.3, 25-48, 1981.

OLIVER, R. L. Whence Consumer Loyalty? Journal of Marketing. Ed. especial. v.63, 1999. 
PRADO, P. H. M. A avaliação do relacionamento sob a ótica do cliente: Um estudo em bancos de varejo. Doctoral Thesis - FGV. p. 497. São Paulo, 2004.

REICHHELD, F.F; SASSER, W.E. Zero Defections: Quality Comes to Services. Harvard Business Review, v.68, n.5, September-October 1990.

REINARTZ, W. J; KUMAR, V. The impact of customer relationship characteristics on profitable lifetime duration. Journal of Marketing. v.67, January 2003.

RYALS, L. Marketing customer relationship management work: The measurement and profitable management of customer relationships. Journal of Marketing. v.68, October 2005.

SIDERSHMUKH, D; SINGH, J; SABOL, B. Consumer Trust, Value, and Loyalty in Relational Exchanges. Journal of Marketing. v.66, n.1, January 2002.

YEUNG, M. C.H; ENNEW, C. T. From customer satisfaction to profitability. Journal of Strategic Marketing, 2000.

YI, Y; JEON, H. Effects of Loyalty Programs on Value Perception, Program Loyalty, and Brand Loyalty. Journal of Academic Marketing Science. v.31, n.3, 2003

ZEITHMAL, V. A. BERRY, L; PARASURAMAN, A. The Behavioral Consequences of Service Quality. Journal of Marketing. n.52, July 1996.

ZEITHMAL, V. A. Consumer Perceptions of Price, Quality, and Value: A Means-End Model and Synthesis of Evidence. Journal of Marketing. v.52, 1988

\footnotetext{
${ }^{1}$ The scale was adapted from the customer satisfaction survey conducted by Anatel in 2004 .
} 